\title{
Nominal slavery, free people of colour, and enslavement requests: slavery and freedom at the 'edges' of the regime in the antebellum South
}

Book or Report Section

Accepted Version

West, E. (2020) Nominal slavery, free people of colour, and enslavement requests: slavery and freedom at the 'edges' of the regime in the antebellum South. In: Aje, L. and Armstrong, C. (eds.) The Many Faces of Slavery: New Perspectives on Slave Ownership and Experiences in the Americas.

Bloomsbury, London, pp. 199-210. ISBN 9781350071421 doi: https://doi.org/10.5040/9781350071452.ch-013 Available at http://centaur.reading.ac.uk/73812/

It is advisable to refer to the publisher's version if you intend to cite from the work. See Guidance on citing.

To link to this article DOI: http://dx.doi.org/10.5040/9781350071452.ch-013

Publisher: Bloomsbury 
All outputs in CentAUR are protected by Intellectual Property Rights law, including copyright law. Copyright and IPR is retained by the creators or other copyright holders. Terms and conditions for use of this material are defined in the End User Agreement.

\section{www.reading.ac.uk/centaur}

\section{CentAUR}

Central Archive at the University of Reading

Reading's research outputs online 


\title{
Nominal Slavery, Free People of Colour and Enslavement Requests: Slavery and Freedom at the 'Edges' of the Regime in the Antebellum South
}

\author{
Emily West
}

In 1856, Virginia became the first Southern state to formalize legislation on so called 'voluntary slavery' (the term is contentious), in keeping with its reputation as a torchbearer for laws about enslavement. Before this time, free people of colour could only become enslaved through special legislative acts, but from 1856 onwards, the state proudly proclaimed that any free man of colour over the age of twenty-one and every free black women over the age of eighteen could choose their master via legislative or court petition if they so desired. Courts would then ascertain the value of the petitioner, after which the 'chosen' slaveholder would pay the court half the individual's value, and enter bond for the rest. Thereafter 'the condition of the petitioner shall in all respects be the same as though the Negro has been born a slave."

After this ruling, Virginia saw a flurry of petitions from free people of colour seeking enslavement, the majority of whom appear to have lived among the enslaved and who were anxious about forcibly being separated from them, especially when they were bound to enslaved people through spousal or other familial ties of affection. And the state was not alone - other Southern legislatures also enacted or debated similar laws about the expulsion or enslavement of free people of colour. Between 1856 and the outbreak of the Civil War, seven states made legislative provisions for the 'voluntary' enslavement of free blacks. These were Alabama, Florida, Louisiana, Maryland, Tennessee, Texas and Virginia. South Carolina and Georgia approved of it by means of special acts of the legislature in individual cases, and the issue was also debated in the legislatures of Delaware, Kentucky, Mississippi, Missouri and North Carolina. Essentially, all Southern states were moving in the longer term towards the enslavement of their free people of colour, and some also considered the forced expulsion of free blacks, including Mississippi, Missouri, Florida and North Carolina. ${ }^{2}$ Inevitably, the outbreak of war diverted attention to the more pressing concerns of conflict, but despite these upheavals the Confederacy continued to regard the enslavement of free people of colour as a means of strengthening its regime. By early 1863, just four days after Lincoln's Emancipation Proclamation, Jefferson Davis decreed all free blacks in the Confederacy should be considered enslaved, although, as David Williams has 
noted, this move proved impossible to enforce as Blacks headed to Union lines in their thousands. ${ }^{3}$

Arkansas went further than all other Southern states in its discriminatory treatment of free people of colour. In February 1859, the state outlawed all emancipations and also famously declared 'no free negro or mulatto to reside in the State after January 1st 1860 . ${ }^{4}$ Convinced that 'removal' was in the best interests of all concerned, late antebellum policymakers in the state seem to have considered the enforced removal of free blacks to be the only viable option to ensure the regime's survival. In this sense their actions can be compared to those of the federal government during the Jacksonian era a generation earlier, when policymakers presented the 'removal' of Native American tribes west of the Mississippi as being in the 'best interests' of both the white and Native American people. ${ }^{5}$ The Arkansas legislature did not pause to question where these expelled free people of colour might go. Instead it offered only one route by which they might 'choose' to stay: namely by 'selecting' a master or mistress and entering slavery. Moreover, a failure to 'select' such an owner put free blacks at risk of being arrested and imprisoned by county sheriffs, and then hired out to the highest bidder, essentially subjecting them to enslavement in a different form whereby the state assumed 'ownership' and 'bidders' gained the labour of the people they hired. Arkansas was hence increasing the flexibility and malleability of its slave regime as it attempted to bring free people of colour into this system. ${ }^{6}$

This chapter explores the lives of the enslaved and free people of colour who lived on the 'edges' of the slave regime, an all-encompassing and useful term coined by the late historian Peter Parish to refer to free people of colour living in the antebellum South, many of whom were the nominal slaves of white people, or 'slaves without masters' according to Ira Berlin's seminal 1974 conceptualization. ${ }^{7}$ Parish also applied the term to urban slaves, those who were hired out and slaves who worked in more industrial contexts. Essentially, Parish encouraged historians to look beyond the plantation paradigm: to shed light on the 'edges' to illuminate the flexibility and malleability of slavery as a whole. Exploring people's lives at the margins of the regime therefore allows historians to reject oversimplistic dichotomies of 'freedom' and 'bondage', and see more of the everyday realities of life for people who lived between the two. Their experiences reveal another 'face' of people's lives under the regime as well as the motivations of slaveholders. The chapter hence traces laws about expulsion and enslavement before considering why free blacks who already lived among the enslaved considered 'voluntary' enslavement a viable option. It will then elaborate on some of these experiences through a case study of some free black families in Mississippi who lived 'in between' slavery and freedom in forms of quasi-slavery, and the impact of Arkansas's 1860 expulsion law upon free people of colour.

The US denied all black people, whether enslaved or free, formal legal citizenship until after the Civil War. Yet with some notable exceptions (mostly focused around more localized studies), most historians of the antebellum South have tended to consider free people of colour and the enslaved in relative isolation from each other. In contrast, this chapter considers the bonds and interactions between free people of colour and the enslaved. And whereas a growing number of historians are devoting attention to the lives of free blacks, especially women, who tried to move from bondage 
to freedom, this chapter instead explores moves from freedom to enslavement. ${ }^{8}$ Significantly, free people of colour did not always live apart from the enslaved. Evidence from the US census, from legislative and county court petitions submitted by free people of colour and from Works Progress Administration (WPA) interviews collated in the 1930s instead suggests that many free black people worked and lived within the households, farms and plantations of white slaveholders under informal systems of bondage, in positions of nominal or quasi-slavery. These people often had affective ties to the enslaved, from whom they did not wish to be separated, especially when Southern states imposed ever-more restrictive laws in relation to free people of colour's mobility over the course of the antebellum era. Moreover, the very existence of free blacks irked pro-slavery advocates who wanted to present enslavement as the most 'appropriate' situation for people of African descent. Hence lawmakers sought to create a clear binary division between Black and White, enslaved and free.

Southern slaveholders, too, increasingly aired their concerns about the existence of free people of colour over the course of the antebellum era. Pro-slavery ideologue George Fitzhugh, for example, even described the very notion of 'a free negro' as an 'absurdity.' Hence the laws passed by Southern states in their attempts to regulate free blacks is testament to how much white slaveholding lawmakers perceived free people of colour as problematic. As early as 1806 Virginia passed a law decreeing that all former slaves manumitted by their owners had to leave the state within one year or else relinquish their liberty, unless they had the permission of county officials to remain. ${ }^{10}$ And, despite free people of colour's valuable economic input, Southern legislatures, via local laws, statutes and ordinances, attempted to prevent the migration of free blacks into states, restricted emancipations, set up complicated systems of registration, taxation and guardianship, and attempted to send some free blacks 'back' to Africa via various colonization initiatives. ${ }^{11}$ While these laws and ordinances were not always easy to enforce, legislative action escalated over time as rising sectional tensions led Southern lawmakers to debate and/or enact ever more restrictive legislation governing the lives of free people of colour, especially in the second half of the 1850s.

Following these legal debates and rulings across the South as a whole, a minority of free people of colour sought recourse to the law in an attempt to move from freedom to bondage. Their often poignant petitions for alleged 'voluntary' enslavement illustrate the sheer desperation and poverty of antebellum free blacks who fought not to move, but to 'remain still' with their families, in their homes, enmeshed in broader communities; they prioritized their immediate affective ties over and above their legal status, and sometimes even their freedom. For these people, there was no clear divide between slavery and freedom, but rather a continuum of racial oppression that also, of course, continued through the Civil War and thereafter when the era of Jim Crow segregation saw ongoing coercion and racialized violence. However, those who sought recourse to the law in an attempt to enter bondage are numerically highly insignificant. The author found just 143 enslavement petitions across the Southern states, while Ted Maris-Wolf's more recent and more focused case study of self-enslavement using evidence from Virginia's county courts found 110 enslavement petitioners within that state alone. ${ }^{12}$ Compared to the total quarter of a million free blacks in the South in 1860 , these numbers are very small indeed. ${ }^{13}$ But these often very desperate people 
reveal much about a different face of enslavement upon its margins, as well as the nature of surviving written sources about slavery which are so often biased towards large, efficiently run plantations. Moreover, despite some regional differences in enslavement and expulsion laws as outlined above, free people of colour lived within enslaved communities in forms of quasi-slavery across the whole South, and their submission of enslavement requests also occurred across the region as a whole. ${ }^{14}$

The 1861 petition of Walker Fitch of Augusta County, Virginia, twenty-one years old in the census of 1860 , is highly typical of these enslavement requests. In his petition to the state legislature, Fitch claimed to be 'weary of freedom'. He argued he wanted to belong to Michael G. Harman, the owner of his wife and children, and the holder of twenty-four enslaved people in total. ${ }^{15}$ According to the 1860 census, which included free people of colour, Fitch did not live in the same household as his enslaved wife and children, although in practice it is highly likely he visited them frequently, especially at weekends. The relationship of Fitch and his wife (who could not legally marry under US law) probably operated in a similar way to those of enslaved couples in 'crossplantation' or 'abroad' marriages, where husbands tended to partake in weekend visits sanctioned by slaveholders at the weekend, but might occasionally also undergo additional 'illicit' midweek visits. ${ }^{16}$

Indeed, the fact that Fitch was not enslaved probably made little difference to Michael Harman. Every child that Fitch's wife bore would belong to him, following the precedent set by an earlier Virginian ruling of 1662, when, in a practice that deviated from most colonial lawmaking (which tended to follow British precedents that favoured patrilineal lines), the rule of partus sequitur ventrem decreed that the offspring of enslaved mothers followed the status of their mothers, and not their fathers. ${ }^{17}$ Historians can do no more than hypothesize about the spousal relationship of Fitch, his wife and their family, but further light can be shed on this couple and their relationship by using census evidence in conjunction with Fitch's enslavement petition to speculate about why he might have wanted to enter slavery 'voluntarily.' ${ }^{18}$

The 1860 census reveals that Fitch lived in a free black household along with his mother, Margaret, and his sister, Elvira, both of whom laboured as washerwomen. Like many other free people of colour in the antebellum South, it is likely the family were poor. ${ }^{19}$ Fitch himself is listed as a 'labourer', and in his petition, Fitch's potential owner, Michael Harman, explained that he owned Fitch's wife and children before describing how Fitch had worked for him for 'several years'. Harman subsequently explained in typically benevolent rhetoric that he was 'willing' to accept Fitch as a slave 'upon equitable terms'. Indeed, the fact that the entire petition is written in Harman's hand arouses suspicion that Harman simply wanted to acquire Fitch, a man of prime labouring and childbearing age, for free.

But Walker Fitch may have had his own reasons for wanting to become enslaved to Michael Harman. As is frustratingly the case for many other enslavement petitions, there is no recorded result for Fitch's request. But he could well have been acting pragmatically. Although his views and opinions are absent from the historical record, Fitch seems to have rejected the dichotomy between slavery and freedom. He was prepared to lose his right to the legal freedom yearned for by so many enslaved people, and he was prepared to work for Harman as a slave rather than as a poorly paid 
labourer. Furthermore, in accepting enslavement, Fitch also had something very important to gain, namely the ability to spend every night in the same bed as his wife, and to enjoy spending time with his children at the end of the working day and at weekends. In short, Fitch could be more immediately involved in the day-to-day life of his beloved family while his everyday labour stayed much the same as it always had. Walker Fitch's everyday life as a potential slave, rather than a free man of colour, can hence be characterized in terms of continuities rather than changes. For Fitch, like many others, there was no sharp delineation between slavery and freedom, but rather a continuum of oppression characterized by degrees of persecution. Walker Fitch was already a slave in all but name, a nominal slave of Michael Harman even before the submission of his enslavement request.

Like Walker Fitch, most free people of colour who submitted enslavement requests wanted simply to stay with their families, in their homes. They therefore responded to the threat of expulsion and/or enslavement in pragmatic ways that prioritized their immediate affective ties over and above their legal status, and sometimes even their freedom. Individual experiences of belonging in a sense of place via emotional attachments to people and areas assumed priority here. Historians often regard people's geographical mobility through a paradigm of positivity, but this does not hold true across time and space, especially in places with oppressive regimes where so much movement has been enforced. As argued by Edlie Wong, the right to movement is essential to modern conceptualizations of freedom, and certainly the freedom to partake in geographical mobility has, and continues to be, important for people. ${ }^{20} \mathrm{But}$ while the enforced curtailing of movement obviously negates one's freedom, the opposite is also true. For example, for enslaved people forced westwards as a part of the internal domestic slave trade, and for free people of colour reacting pragmatically to expulsion and enslavement laws, geographical mobility was something enforced and undesirable. These people simply wanted to be still, to remain with the people they loved.

Enslaved people and poor free people of colour were early pioneers in marrying for reasons of romantic love. Devoid of wealth and property, arranged marriages (informal or otherwise) bore no relevance for antebellum black Southerners, in contrast to patterns of wedlock among elite white Southerners, for whom the preservation of familial money was important to the maintenance of power networks. ${ }^{21}$ Instead, antebellum black Southerners married for love. An unnamed formerly enslaved man from Henry County, Tennessee, told his Fisk University interviewer in the late 1930s that:

I knowed a man named Wyatt who was free and he wanted to marry a slave girl name Carrie, and he gave himself to Carrie's master to marry her. That love is an awful thing, I tell you. What I woulda done was to go off and send for her later on. He was crazy to do that. ${ }^{22}$

The interviewee wrote off Wyatt as 'crazy', sacrificing his very liberty for the love of the woman, Carrie, whom he wanted to marry. But of course Wyatt didn't know that slavery would be abolished in 1865, and he made a pragmatic decision, albeit one governed by 
his heart, to live with his sweetheart in wedlock, by 'gifting' himself, as a slave, to Carrie's owner. Poignantly, all he had to offer was his own potential value as a black man who could become chattel. It is unknown how this arrangement worked at a practical level. Did Carrie's master seek recourse to the law in an attempt to formalize his ownership of Wyatt or did the arrangement operate on a more informal, ad hoc basis? Did Carrie's master simply 'assume' ownership of Wyatt and provide him with a home, food, clothing and other necessary items in return for Wyatt's unpaid labour and the 'freedom' to live with his wife? At the margins - the edges - of the regime, slavery was complicated and often raises more questions than it answers.

There are numerous instances of wedlock between enslaved people and free blacks contained within the Works Progress Administration (WPA) interviews with formerly enslaved (and free black) people in the 1930s, of which the case of Wyatt, detailed above, provides just one example. ${ }^{23}$ Take Emma Stone, who lived with her free black mother, her nine siblings and her enslaved father on the Bell family plantation in North Carolina. 'We wuz', she said 'just lak de udder slaves. ${ }^{24}$ In Texas, Mary Reynolds' free black father attempted to negotiate with his wife's owner to buy her from him. But Dr Kilpatrick was well aware of this woman's value to him both as a worker and reproducer.'Dr Kilpatrick was never one to sell any but the old niggers who was past workin' in the fields and past their breedin' times', Mary recalled. So 'my paw married my maw and works in the field the same as any other nigger'. They had six daughters, including Mary, and her father appears to have lived in quasi-slavery. ${ }^{25}$ Likewise, Laura Hart, enslaved in Arkansas, described how her father attempted to buy her mother from her master, Sam Carson, who refused to sell. Laura Hart then explained how her father 'stayed with old man Carson till they was all free. ${ }^{26}$ Samuel Small explained how his free black father spent seven years working on the Florida plantation of his mother's master, unpaid, because he would not leave her. ${ }^{27}$ These scattered examples among many others reveal the real strength of romantic ties of affection, as well as significant interaction along the blurred line between slavery and freedom for black Southerners.

Other cases of quasi-slavery at the edges of the regime can be found through a careful combination of archival research, supplemented by probing the US census and sometimes adding in a jot of speculation as well. The situation of the Lundy family of Pike County, Mississippi, provides a good example of this. In 1854 the Pike County Board of Police authorized a public auction to hire out a number of free blacks in the county with the surname Lundy. The policy was designed to raise a fund of some $\$ 6,000$ to ship the Lundys to Liberia and provide for them for one year thereafter - so removing the 'problem' of these free blacks in the state - but it is unknown whether the Lundys themselves were instrumental in initiating this colonization request. ${ }^{28}$

The 1850 census shows twenty-six black or 'mulatto' people with the surname Lundy living in Pike County, fifteen of whom lived in one large multigenerational farming household - a common family formation for people living in poverty across a variety of different times and spaces. Extended families provide additional labour for financial support and women can share childcare responsibilities. But, looking up the other Lundys in the census reveals something more unusual. Spread throughout eight white headed households in the county were a number of free black Lundy children, of 
whom the eldest, John, was fifteen while the youngest, Celia and Bob, were six. These Lundy children seem to have already been hired out to white families, either alone or in pairs, either to earn additional money or to spare the Lundy household from the financial burden of raising then. They probably performed small domestic chores and helped with children. In short, their labour was practically the same as that of enslaved children. ${ }^{29}$ Moreover, the Lundys were probably unaware of any legal rights they possessed as free people of colour rather than slaves because they were children or adolescents.

So the notion that these Lundy children were 'free' people of colour is rendered rather hollow by the realities of their everyday existence in which they laboured under systems of servitude and dependency despite their legal status as free people of colour and the limited protections under the law that status brought. Racial slavery meant many manifestations of exploitation, and not just for those legally enslaved. Moreover, using census and slave schedule evidence to track the family formations of the white families with whom the Lundy children resided reveals that all eight households held a number of slaves in addition to the 'free' black Lundy children. For example, fifteenyear-old John Lundy lived with the Stallins who owned five enslaved people. Sarah Lundy resided in the home of the Lamkin family along with their forty-two slaves. No doubt the Stallin and Lamkin families treated John and Sarah Lundy in much the same way as their chattel - they were slaves in all but name and part of broader enslaved communities despite their free status. ${ }^{30}$ In the longer term, attempts to raise enough money to ship the Lundys to Liberia appear to have failed. Twenty members of the family appear on the 1860 census for Pike County, many of whom lived within the same white households for whom they still laboured. ${ }^{31}$ The Lundy family's experiences suggest forms of de facto slavery and informal systems of hiring out for free people of colour both before and during the Civil War.

Across the border in Arkansas, the state's harsh expulsion law of 1860 meant that free blacks were not permitted to live within the state after that date. Those who stayed had to 'choose' slavery instead. Historians have estimated there were only around 700 free people of colour in Arkansas at the time of this ruling, most of whom chose to flee. ${ }^{32}$ For example, Billy Higgins has illustrated how one free black community in Marion County diminished by 120 , leaving only eight individuals in the area. Oppressive laws therefore rendered the free black population of Arkansas virtually extinct, but because these people often left no written sources, historians can only hypothesize about their movements. Higgins wrote:

... their [free people of colour's] decision to go raises several questions. Was their departure forced by Marion County whites ...? Did the community travel to a common destination together, or did they leave individually, each seeking to find new beginnings in another place? ${ }^{33}$

At the dawn of a new decade, free people of colour in Arkansas found themselves in a truly desperate situation. Leaving the state collectively - in groups that included beloved family and community members - was certainly an option. But what about free blacks whose primary affective ties were to the enslaved? They faced heartbreaking 
dilemmas including whether simply to 'lie low', to 'be still' and hope for better times ahead, or to leave, sometimes without their loved ones.

Choosing the former could be a risky strategy, however. County sheriffs caught at least a handful of free black people living illegally in Arkansas, all of whom were forced into slavery. For example, the Pulaski County sheriff captured Robert Deam in 1860 for living in the state 'contrary to law'. He appeared in open court and then 'selected' Thomas Yell as his new master. The language used is chilling since Robert Deam had no real choice beyond enslavement or expulsion. Aged fifty-five and valued at just $\$ 250$, Thomas Yell had to pay just half that amount to the County treasury. Moreover, the 1850 census shows Robert Deam already living with the Yell family, where he worked as a labourer. So he 'chose' to stay with his family in the place he called home. Deam then poignantly disappears from the 1860 census because he had entered slavery, but the associated slave schedules show Thomas Yell owning eleven slaves, one a fifty-fiveyear-old man, presumably Robert, another a woman of sixty who may have been Robert's spouse and a number of other slaves, some of whom may have been their children (the slave schedules only give lists of enslaved people) ${ }^{34}$ Robert Deam's move into bondage, although against his will, can be characterized in terms of continuities rather than changes. Faced with the stark and bewildering 'choice' of expulsion or enslavement, he accepted the latter in order to remain at home with his beloved family.

\section{Conclusion}

Arkansas went further than other Southern states in its restrictive legislation directed against free people of colour because no other Southern legislature passed a law designed to expel all free blacks. However, the fact that other states debated and sometimes legislated on what they termed 'voluntary' slavery suggests the South as a whole was attempting to make free people of colour's lives less tolerable, and ultimately to separate free people of colour from the enslaved by creating a biracial system of free whites and enslaved blacks. But despite these moves by the white men of government, slaves and free people of colour formed families, homes and communities across this often arbitrary divide, which they fought to preserve in pragmatic ways. Many free people of colour were already de facto slaves in the households of white families, families to whom some later sought enslavement. Ira Berlin famously described free blacks as 'slaves without masters', but ironically, some antebellum free people of colour were already subject to a kind of quasi-slavery with masters. ${ }^{35}$

Relatively overlooked by historians, understanding the lives of free people of colour in the antebellum South is important. As Ira Berlin has noted, the origins of various post-emancipation racial institutions such as the black codes, sharecropping and segregation can be found specifically in antebellum legislation directed against free blacks. ${ }^{36}$ But despite the strenuous efforts by white Southerners to create a biracial system of plantation-based slavery, there remained diverse and contested middle grounds in between slavery and freedom where the enslaved, free blacks and poorer Whites interacted in a variety of ways. During a climate of changing, and ever-more hostile, laws, exploring the lives of free people of colour along the 'edges' of the regime 
provides a useful 'way in' for historians interested in exploring further ties between the enslaved and free people of colour, relationships between free blacks and Whites, and what these social and economic relationships reveal more broadly about interactions along the all-too hazy boundary between slavery and freedom.

\section{Notes}

1 'An Act Providing for the Voluntary Enslavement of Free Negroes of the Commonwealth', passed on 18 February 1856, chapter 46,37-8. Acts of the General Assembly of Virginia, 1855-1856 (Richmond: John Worrock, printer to the Senate, 1856), Library of Virginia, Richmond (hereafter LVA). See also Ira Berlin, Slaves Without Masters: The Free Negro in the Antebellum South (New York: Pantheon, 1974), 260-4, 371; John H. Russell, The Free Negro in Virginia, 1619-1865 (New York: Dover, 1969), 107-9; June Purcell Guild, Black Laws of Virginia: A Summary of the Legislative Acts of Virginia Concerning Negroes from the Earliest Times to the Present (Richmond: Whittet and Shepperson, 1936), 121. Some of the arguments presented in this chapter are explored in more detail in Emily West, Family or Freedom: People of Color in the Antebellum South (Lexington: University Press of Kentucky, 2012).

2 Of the five states that did not legislate on 'voluntary' slavery, four were in the Upper South. But only Delaware's free black population stood at over 10 per cent of the total number of free people of colour. There was no correlation between the relative size of the free black population and legislative action on enslavement, nor was there a link between the geographic location of states and the desire to legislate. For more on these legal moves, see Thomas D. Morris, Southern Slavery and the Law, 1619-1860 (Chapel Hill and London: University of North Carolina Press, 1996); and West, Family or Freedom, chap. 1.

3 David Williams, I Freed Myself: African American Self-Emancipation in the Civil War Era (New York: Cambridge University Press, 2014), 128-9.

4 'An Act to Remove the Free Negroes and Mulattoes from this State' (number 151), approved 12 February 1859. Acts Passed at the Twelfth Session of the General Assembly of the State of Arkansas, 1858-9. Acts of Arkansas, 175-8, Arkansas History Commission and State Archives, Little Rock (hereafter AHCSA).

5 Theda Perdue argues that Native American Removal was a process of ethnic cleansing. See 'The Legacy of Indian Removal', Journal of Southern History 77, no. 1 (2012): 3-36, esp. 28.

6 'An Act to Remove the Free Negroes and Mulattoes from this State', 175-8, AHCSA.

7 See Peter Parish, 'The Edges of Slavery in the Old South: Or, do Exceptions Prove Rules?', Slavery and Abolition 4, no. 1 (1983): 106-25. See also his book, Slavery: History and Historians (New York: Harper and Row, 1989), chap. 6; Berlin, Slaves Without Masters.

8 In addition to Berlin's Slaves Without Masters, see also John Hope Franklin, The Free Negro in North Carolina, 1790-1860, 3rd edn (Chapel Hill: University of North Carolina Press, 1995); Michael P. Johnson and James L. Roark, No Chariot Let down: Charleston's Free People of Color on the Eve of the Civil War (New York: Norton, 1984). Jane Landers considers free blacks across Atlantic slave societies in Against the Odds: Free Blacks in the Slave Societies of the Americas (London: Frank Cass, 1996), as do David Barry Gaspar and Darlene Clark Hine (eds), in Beyond Bondage: Free Women of 
Color in the Americas (Urbana: University of Illinois Press, 2004). For more recent works on free people of colour (especially women) in the US, see Wilma King, The Essence of Liberty: Free Black Women in the Slave Era (Columbia: University of Missouri Press, 2006); Jessica Millward, Finding Charity's Folk: Enslaved and Free Black Women in Maryland (Athens: University of Georgia Press, 2015); Amrita Chakrabarti Myers, Forging Freedom: Black Women and the Pursuit of Liberty in Antebellum Charleston (Chapel Hill: University of North Carolina Press, 2011); and Judith Kelleher Schafer, Becoming Free, Remaining Free: Manumission and Enslavement in New Orleans, 1846-1862 (Baton Rouge: Louisiana State University Press, 2003).

9 George Fitzhugh, Sociology for the South; Or, the Failure of Free Society (Richmond, VA: A. Morris, 1854), 264.

10 Quoted in Peter Wallenstein, Tell the Court I love My Wife: Race, Marriage and the Law - An American History (London: Palgrave MacMillan, 2002), 21.

11 For an overview of these laws, statutes and ordinances across the South, see West, Family or Freedom, chap. 1.

12 Ted Maris-Wolf, Family Bonds: Free Blacks and Re-enslavement Law in Antebellum Virginia (Chapel Hill: University of North Carolina Press, 2015), 21.

13 John Boles, Black Southerners, 1619-1869 (Lexington: University Press of Kentucky, 1983), 135.

14 For a more detailed analysis, see West, Family or Freedom, esp. chap. 1.

15 Petition of Walker Fitch, Race and Slavery Petitions Project, University of North Carolina at Greensboro. Each petition holds a unique Petition Analysis Record number, in this case PAR 11686102. See https://library.uncg.edu/slavery/petitions/. 'Slave Inhabitants in Staunton District Number 1, County of Augusta, State of Virginia, Enumerated on 20th June 1860', 11. All US census information (including that from the slave schedules) has been obtained via ancestry.com.

161860 Census for Staunton, Augusta, Virginia, roll m653 1333, 786, image 266. Family History Library Film 805333. For more on the cross-plantation marriages of enslaved people, see Emily West, Chains of Love: Slave Couples in Antebellum South Carolina (Urbana and Chicago: University of Illinois Press, 2004), chap. 2.

17 Jennifer Morgan, Laboring Women: Reproduction and Gender in New World Slavery (Philadelphia: University of Pennsylvania Press, 2004); 71-2.

18 Stephanie Camp argues persuasively that historians use their imagination in the absence of written testimony: Stephanie Camp, Closer to Freedom: Enslaved Women and Everyday Resistance in the Plantation South (Chapel Hill and London: University of North Carolina Press, 2004), 95.

19 Julie Winch, Between Slavery and Freedom: Free People of Color in America from Settlement to the Civil War (Lanham, MD: Rowman and Littlefield, 2014), 63-71.

20 Edlie L. Wong, Neither Fugitive nor Free: Atlantic Slavery, Freedom Suits, and the Legal Culture of Travel (New York and London: New York University Press, 2009) 242-3.

21 For more on romantic love among enslaved people in the antebellum South, see West, Chains of Love, chap. 1.

22 George P. Rawick, The American Slave: A Composite Autobiography, vol. 18: The Unwritten History of Slavery (Westport, CT: Greenwood Press, 1972), 284.

23 Of course enslaved people (and enslaved people and free people of colour) could not marry under US law as they were not citizens. But most entered wedlock after undergoing some sort of formal ceremony. For more on black marriage, See Tera W. Hunter, Bound in Wedlock: Slave and Free Black Marriage in the Nineteenth Century (Cambridge, MA, and London: Belknap Press, 2017), especially chaps 1 and 3. 
24 Emma Stone, Federal Writers' Project: Slave Narrative Project, vol. 11: North Carolina, Part 2, Jackson-Yellerday, 329. Accessed via the Library of Congress website: https:// www.loc.gov/collections/slave-narratives-from-the-federal-writers-project-1936to-1938/about-this-collection/ (hereafter LoC).

25 Mary Reynolds in George P. Rawick, The American Slave, Supplement Series 2, vol. 8: Texas Narratives Part 7 (Westport, CT: Greenwood Press, 1979), 3284. Larry Koger has referred to the practice of free blacks purchasing enslaved spouses as 'nominal slavery'. See Larry Koger, Black Slaveowners: Free Black Slave Masters in South Carolina, 1790-1860 (London: McFarland, 1985), 69. See also Hunter, Bound in Wedlock, 93-5.

26 Laura Hart, Federal Writers' Project: Slave Narrative Project, vol. 2: Arkansas, Part 3, Gadson-Isom, 192, LoC.

27 Samuel Smalls, Federal Writers' Project: Slave Narrative Project, vol. 3: Florida, Anderson-Wilson (with combined interviews of others), 303-4, LoC. These experiences are being developed into a further article by the author, "We chilluns, long wid her, wuz lak de udder slaves": Free black families and "quasi-slavery" in the pre-Civil War US South' (in progress).

28 'An Act to Empower the Board of Police of Pike County to Remove the Lundy Free Negroes Living in Said County to Liberia', approved 10 February 1854. Laws of the State of Mississippi, Passed at a Regular Session of the Mississippi Legislature Held in the City of Jackson (Jackson, MS: E. Barksdale, State Printer, 1854), 287-8. Mississippi Department of Archives and History (MDAH hereafter).

29 For a detailed summary of the Lundy family children, see West, Family or Freedom, $68-9$.

301850 Census, Police District 1, Pike, Mississippi, roll M432 380, 19A, image 42, and 1B, image 7. 'Slave Inhabitants in the County of Pike, State of Mississippi, Enumerated on the 30th August 1850', 3.

31 See West, Family or Freedom, 69-70.

32 Margaret Ross, 'Mulattoes, Free Negroes Ordered to Leave Arkansas on Eve of War', Arkansas Gazette, 15 February 1959, 3E. She claims only 144 free blacks remained, all of whom were rather elderly, a number also cited by Ira Berlin. See Berlin, Slaves Without Masters, 373-4, and Morris, Southern Slavery and the Law, 30-1.

33 Billy D. Higgins, 'The Origins and Fate of the Marion County Free Black Community', Arkansas Historical Quarterly 54 (Winter 1995): 440.

34 Entry for 17 May 1860, microfilm roll misc.39, Circuit Court Record Book 'Z' (Civil), May 1859-July 1863, Pulaski County, Arkansas, 281. AHCSA; 1850 census for Vaugine, Jefferson, Arkansas, roll M432 27, 75A, image 154; 'Slave Inhabitants in Campbell Township in the County of Pulaski, State of Arkansas, Enumerated on the 27th July $1860,7$.

35 See Berlin, Slaves Without Masters.

36 Ira Berlin, 'Southern Free People of Color in the Age of William Johnson', Southern Quarterly 43, no.2 (2006): 10-15. 
